\title{
Preferential PCR Amplification of Alleles: Mechanisms and Solutions
}

\author{
P. Sean Walsh, Henry A. Erlich, and Russell Higuchi \\ Department of Human Genetics, Roche Molecular Systems \\ Emeryville, California 94608
}

The preferential PCR amplification of one allele relative to another in a heterozygous sample could result in an incorrect or ambiguous genetic typing of that sample. There are several mechanisms that could potentially lead to such preferential PCR amplification. First, preferential amplification can result from significant GC\% differences between alleles if the conditions of the reaction (denaturation temperature $\left(T_{\text {den }}\right)$, duration at the $T_{\text {den' }}$ salt and co-solvent concentrations, etc.) allow the denaturation of one allele but not the other (differential denaturation). For example, the DQa1.1, -1.2, and -1.3 alleles of the HLA-DQa locus do not amplify at a $T_{\text {den }}<89^{\circ} \mathrm{C}$; these same conditions still allow amplification of the DQa2, -3, and -4 alleles. However, no differences in amplification efficiency were found between the different HLA-DQa alleles when the $T_{\text {den }}$ was set at the recommended $T_{\text {den }}$ of $94^{\circ} \mathrm{C}$, even after as many as 102 cycles of amplification. Second, for PCR-based genetic typing systems in which the PCR products from different alleles differ in length, preferential amplification of the shorter allelic product can occur. Experiments in which the variable number tandem repeat (VNTR) marker D1755 (YNZ22) was amplified under various conditions suggest that the smaller allelic products are amplified preferentially when Taq polymerase is limiting. Preferential amplification of VNTR alleles can also occur if the target DNA is sufficiently degraded. Third, when the initial number of genomes sampled is very small, stochastic fluctuation in the number of copies of each allele can result in what appears to be preferential amplification. Finally, less efficient priming of DNA synthesis of one allele versus another can occur because of mismatches between the primer and the specific allelic template, resulting in preferential amplification of the other allele. General strategies to avoid preferential amplification are discussed.

he method of PCR amplification, an automated in vitro procedure for the enzymatic synthesis of a specific DNA fragment, has become widely used in genetic typing, as well as in many other research and diagnostic areas. $(1,2)$ PCR is based on repeated cycles of target DNA denaturation and oligonucleotide primer extension on the single-stranded template. ${ }^{(3)}$ Genetic typing involves the amplification of a specific genomic DNA segment that is polymorphic or that may contain mutations and the subsequent determination of the alleles by any of a variety of techniques. Here, we discuss the mechanisms that, under certain circumstances, might lead to the preferential amplification of one allele relative to the other, and the strategies to avoid this potential PCR artifact.

Preferential amplification potentially could occur if the amplification products representing two alleles in a heterozygous sample denature at different temperatures (differential denaturation). In this case, it is possible that the allele that denatures less efficiently will not be detected, thus resulting in an incorrect genetic typing of that sample. Differential priming of synthesis of an allele can also lead to preferential amplification. Allele-specific amplification based on the inefficient extension of oligonucleotide primers mismatched with the template at the $3^{\prime}$ end is a well-established PCR strategy. ${ }^{(4,5)}$ The amplification of variable number tandem repeat (VNTR) regions using primers complementary to unique sequences that flank the repeat region generates PCR products of different lengths, based on the number of repeats in the allelic template. The allelic "types" are determined by measuring the lengths of the PCR products by, for example, gel electrophoresis. In some circumstances, the shorter PCR product is amplified preferentially, sometimes to the extent that the sample could be mistyped. In this paper, we focus on the sequence polymorphism at the HLA-DQ $\alpha$ locus and on the length polymorphism at the D17S5 (YNZ22) locus to explore the mechanisms underlying preferential amplification.

Sequence polymorphism at the HLA-DQ $\alpha$ locus can be analyzed using PCR and immobilized sequence-specific oligonucleotide probes. ${ }^{(6)}$ Eight alleles have been identified with this typing system, and the six most common alleles $(1.1,1.2,1.3,2,3,4$ or *0101, *0102, *0103, ${ }^{\star} 0201,{ }^{\star} 0301$, *0501, respectively in WHO nomenclature; see Materials and Methods) are distinguished in a commercial HLADQ $\alpha$ typing kit, the AmpliType HLADq $\alpha$ Forensic DNA Amplification and Typing Kit (see Materials and Methods). During the development of the AmpliType kit, it was observed that the DQ $\alpha 1.1$ allele was not always detected in a DQ $\alpha 1.1,4$ sample. $^{(7,8)}$ This same phenomenon was also found to occur with the DQ $\alpha 1.2$ and $D Q \alpha 1.3$ alleles. ${ }^{(8)}$ 
In this paper, we show that the $D Q \alpha 1$ alleles do not amplify under some conditions that allow amplification of the DQ $\alpha 2,-3$, and -4 alleles; this preferential amplification has been related to the denaturation temperature $\left(T_{\text {den }}\right)$ during the PCR cycle. The DQ $\alpha 1$ alleles have regions of higher $\mathrm{GC}$ content, and consequently, PCR products generated from the DQ $\alpha 1$ alleles require a higher temperature for complete denaturation than do products from non-DQ $\alpha 1$ alleles. Thus, there is a narrow range of $T_{\text {den }}\left(87-89^{\circ} \mathrm{C}\right)$ where the $D Q \alpha 2,-3$, and -4 alleles but not the DQ $\alpha 1$ alleles amplify. We have investigated the mechanism and properties of preferential amplification in the HLA$\mathrm{DQ} \alpha$ system by comparing the results obtained at various $T_{\text {den }}\left(86-94^{\circ} \mathrm{C}\right)$ in both the original Perkin-Elmer Cetus thermal cycler (model TC) and the newer model TC480 thermal cycler.

Stochastic fluctuation (sampling error) due to initiating a reaction from a heterozygous sample with a very low number of templates can also lead to what appears to be preferential amplification. This phenomenon was examined by amplifying the HLA-DQ $\alpha$ region from a dilution of DNA from a DQ $\alpha 1.3,2$ heterozygote.

Preferential amplification of PCR products of different lengths has been observed in the analysis of VNTR regions $^{(9)}$ and various explanations have been suggested. To investigate this phenomenon, we have varied the $T_{\text {den }}$ cycle number, and enzyme concentration in the amplification of the D17S5 locus.

\section{MATERIALS AND METHODS}

\section{DQa Amplification}

Sample DNA was added to $100 \mu \mathrm{l}$ of PCR Mix, containing $50 \mathrm{mM} \mathrm{KCl}, 10$ $\mathrm{mM}$ Tris- $\mathrm{HCl}(\mathrm{pH} 8.3), 4 \mathrm{~mm} \mathrm{MgCl}_{2}$, $187 \mu \mathrm{M}$ of each dATP, dCTP, dGTP, and dTTP, 20 pmoles of each biotinylated primer GH26 and $\mathrm{GH} 27,(10)$ and 2.9 units of Taq DNA polymerase (PerkinElmer Cetus, Norwalk, CT). The cycling reaction was carried out in a programmable heat block (DNA Thermal Cycler model TC or TC480; Perkin-Elmer Cetus) set to heat at $94^{\circ} \mathrm{C}$ (unless otherwise indicated) for $60 \mathrm{sec}$ (denature), incubate at $60^{\circ} \mathrm{C}$ for $30 \mathrm{sec}$ (anneal), and incubate at $72^{\circ} \mathrm{C}$ for $30 \mathrm{sec}$ (extend) by the "step-cycle" program. After 32 cycles (unless otherwise indi- cated), the samples were incubated an additional $7 \mathrm{~min}$ at $72^{\circ} \mathrm{C}$.

\section{DQa Typing}

To each DNA Probe Strip (AmpliType, HLA $\alpha$ Forensic DNA Amplification and Typing Kit, Cetus Corp., Emeryville, CA) containing immobilized probes, ${ }^{(6)}$ $3 \mathrm{ml}$ of hybridization solution containing $5 \times$ SSPE, $0.5 \%$ SDS, and $300 \mathrm{ng}$ of streptavidin-horseradish peroxidase conjugate (Cetus Corp., Emeryville, CA) was added. PCR-amplified DNA (35 $\mu \mathrm{l}$ ) was denatured by heating at $95^{\circ} \mathrm{C}$ for several minutes and then immediately added to the hybridization solution, which was then incubated at $55^{\circ} \mathrm{C}$ for $20 \mathrm{~min}$. The Probe Strips were briefly rinsed once in $2.5 \times \mathrm{SSPE} / 0.1 \%$ SDS at room temperature, and then washed once in $2.5 \times$ SSPE/0.1\% SDS at $55^{\circ} \mathrm{C}$ for $12 \mathrm{~min}$. The Probe Strips were then washed once in $2.5 \times$ SSPE/0.1\% SDS and once in $0.1 \mathrm{M}$ sodium citrate ( $\mathrm{pH}$ 5.0). Color development was performed by incubating the Probe Strips at room temperature in $0.1 \mathrm{M}$ sodium citrate ( $\mathrm{pH} 5.0$ ) containing $0.1 \mathrm{mg} / \mathrm{ml}$ of $\quad 3,3^{\prime}, 5,5^{\prime}$-tetramethylbenzidine (Fluka Chemical Corp., Ronkonkoma, NY), and $0.003 \%$ hydrogen peroxide.

\section{Nomenclature}

According to most recent system of nomenclature adopted by the World Health Organization HLA Nomenclature Committee, ${ }^{(11)}$ the DQ $\alpha$ locus is now known as DQA1, and the linked and homologous locus, previously known as DXa, is now termed DQA2. The WHO allelic designations are DQA1*0101 (previously 1.1), *0102 (previously 1.2), *0103 (previously 1.3), DQA1*0201 (previously 2), DQA1*0301 (previously 3), DQA1*0401 (previously 4.2), DQA1*0501 (previously 4.1), and DQA1"0601 (previously 4.3). In the present paper we have retained the older nomenclature.

\section{Amplification of Denatured Genomic DNA, Native Genomic DNA, and PCR Product at Low $\boldsymbol{T}_{\text {den }}$}

Denatured genomic DNA (boiled for 5 min), native genomic DNA (nondenatured), or dilute PCR product, all of DQ $\alpha$ type $1.1,4$, were added to PCR Mix as described above. There were an estimated 300 copies of the target DQ $\alpha$ sequences in each of these samples.
The samples were amplified in a model TC thermal cycler for 32 cycles as described above, except the $T_{\text {den }}$ was set at either $87^{\circ} \mathrm{C}, 88^{\circ} \mathrm{C}, 89^{\circ} \mathrm{C}$, or $90^{\circ} \mathrm{C}$. $\mathrm{DQ} \alpha$ typing was then performed on the amplified DNA.

\section{Calculation of $T_{m}$ as a Function of Nucleotide Position for the DQa Sequences}

The computer program MELT ${ }^{(12)}$ was used to calculate $T_{\mathrm{m}}$ (temperature of melting) as a function of nucleotide position along the amplified portion of each of the DQ $\alpha$ allele sequences. This program computes the theoretical melting profile of a DNA sequence and indicates domains within the sequence that might denature independently of one another.

\section{Test for Differences in Amplification Efficiency Between DQa Alleles at $94^{\circ} \mathrm{C} T_{\text {den }}$}

DNA samples heterozygous at the DQ $\alpha$ locus representing a variety of different paired alleles were chosen. The DQ $\alpha$ types of these DNAs were as follows: $1.1,2 ; 1.2,3 ; 1.3,4 ; 2,3 ; 2,4 ; 3,4$. Ten nanograms of each of these DNA samples was amplified for 34 cycles as described above. A 10- $\mu$ l aliquot of the resulting PCR product for each sample was then diluted in TE buffer $(0.01 \mathrm{M}$ Tris- $\mathrm{HCl}, \mathrm{pH} 8,0.1 \mathrm{mM}$ EDTA) by a factor of approximately $6 \times 10^{6}$. Ten microliters of this dilution was then added to a fresh PCR Mix and amplified another 34 cycles. A 10- $\mu$ l aliquot of the PCR product generated from this second reaction was then again diluted by a factor of approximately $6 \times 10^{6}$, and $10 \mu \mathrm{l}$ of this dilution was amplified another 34 cycles. DQ $\alpha$ typing was carried out on the PCR product obtained at each stage of the experiment, corresponding to 34,68 , and 102 cycles of amplification.

\section{Amplification of DQa1.1,4 DNA in All 48 Wells of the Thermal Cycler Heat Block at $94^{\circ} \mathrm{C} T_{\text {den }}$}

Human genomic DNA of DQ $\alpha$ type 1.1,4 was amplified in each of the 48 wells of the thermal cycler heat block, using a model TC thermal cycler. One nanogram of DNA was added to each PCR Mix, and the samples were amplified for 34 cycles using the following cycling parameters: $94^{\circ} \mathrm{C}$ for 60 
$\mathrm{sec}, 60^{\circ} \mathrm{C}$ for $30 \mathrm{sec}, 72^{\circ} \mathrm{C}$ for $30 \mathrm{sec}$ ("step-cycle" program). DQ $\alpha$ typing was performed on the amplified samples, as described above.

\section{Effect of Various Treatments and Additions to Input DNA and PCR Mix on Preferential Amplification}

Various treatments were applied to either input DNA (DQ $1.1,4)$ or the PCR Mix, as described below, and samples were amplified for 32 cycles using the following cycling conditions: $89^{\circ} \mathrm{C}$ for $60 \mathrm{sec}, 60^{\circ} \mathrm{C}$ for $30 \mathrm{sec}, 72^{\circ} \mathrm{C}$ for $30 \mathrm{sec}$ ("step-cycle" program). For each experiment, two control (nontreated) samples and five replicates of each treatment were amplified. The control samples were prepared by adding $20 \mathrm{ng}$ of denatured genomic DNA to a standard PCR Mix (this DNA was denatured prior to addition to the PCR Mix by heating for $10 \mathrm{~min}$ at $95^{\circ} \mathrm{C}$ in TE buffer). Treatments to input DNA were as follows: (1) purified DNA boiled in a solution of $5 \%$ (wt/vol) Chelex (Chelex 100, Bio-Rad, Richmond, CA; ref. 13); $20 \mathrm{ng}$ of this Chelex-boiled DNA was then added to PCR Mix; (2) DNA extracted from a $3-\mathrm{mm}^{2}$ bloodstain using extraction protocols described ${ }^{(13)}$ using Chelex; $20 \mu \mathrm{l}$ of this extract was then added to PCR Mix (Chelex treatment was tested because Chelex is used in a common method of DNA extraction for PCR described in ref. 13); (3) $200 \mathrm{ng}$ of denatured genomic input DNA (vs. $20 \mathrm{ng}$ input for the control). The treatments to the PCR Mix were prepared by adding various salts to standard PCR Mix, as follows: (4) $8 \mathrm{mM} \mathrm{MgCl}_{2}$ (vs. $4 \mathrm{~mm}$ control); (5) $100 \mathrm{mM} \mathrm{KCl}$ (vs. $50 \mathrm{mM}$ control); (6) $60 \mathrm{mM} \mathrm{NaCl}$ (vs. none for the control); (7) $120 \mathrm{~mm}$ ammonium acetate (vs. none for the control). Twenty nanograms of denatured genomic DNA (DQ $\alpha 1.1,4)$ was added to each of the above treated PCR Mixes before amplification. The five treated samples for each experiment were amplified in wells B1, B3, B4, B5, and $B 7$ and the control samples were amplified in wells B2 and B6 of the model TC thermal cycler; DQ $\alpha$ typing was performed as described in Materials and Methods. For $\mathrm{KCl}$, the experiment was repeated using a $T_{\text {den }}$ of $91^{\circ} \mathrm{C}$; for $\mathrm{NaCl}$, it was repeated using a $T_{\text {den }}$ of $91^{\circ} \mathrm{C}$; and for ammonium acetate it was repeated at $T_{\text {den }}$ of $91^{\circ} \mathrm{C}$ and $92^{\circ} \mathrm{C}$.

\section{Comparison of Preferential Amplification of Samples in the Model TC and TC480 Thermal Cyclers}

Twenty nanograms of denatured genomic DNA of DQ $\alpha$ type $1.1,4$ was amplified in each of the 48 wells of the thermal cycler heat block, using a model TC thermal cycler and two examples of the model TC480 thermal cyclers (Perkin-Elmer Cetus, Norwalk, CT). The samples were amplified for 32 cycles using the following amplification profile: $T_{\text {den }}$ for $60 \mathrm{sec}, 60^{\circ} \mathrm{C}$ for $30 \mathrm{sec}$, and $72^{\circ} \mathrm{C}$ for $30 \mathrm{sec}$ ("stepcycle" program). The $T_{\text {den }}$ was set at $89^{\circ} \mathrm{C}$ or $90^{\circ} \mathrm{C}$ for the model TC thermal cycler, $88^{\circ} \mathrm{C}$ for one TC480, and either $90^{\circ} \mathrm{C}, 89^{\circ} \mathrm{C}, 88^{\circ} \mathrm{C}, 87^{\circ} \mathrm{C}$, or $86^{\circ} \mathrm{C}$ for the other TC480. DQ $\alpha$ typing was performed on the amplified samples, as described in Materials and Methods.

An electronic thermometer (Omega model $\mathrm{HH}-72 \mathrm{~T}$ ) and type $\mathrm{T}$ thermocouple were used to measure the temperatures of several wells of the thermal cycler heat blocks after a 10min soak at $89^{\circ} \mathrm{C} .{ }^{(7)}$

\section{DQa Amplification of Low Numbers of Copies of Genomic DNA}

Human genomic DNA of DQ $\alpha$ type $1.3,2$ was diluted in TE buffer to a final concentration of $2.5 \mathrm{pg} / \mu \mathrm{l}$. Ten microliters of this dilution (about 7 copies, on average) was then added to PCR Mix and amplified for 32 or 34 cycles using the following cycling parameters: $94^{\circ} \mathrm{C}$ for $60 \mathrm{sec}, 60^{\circ} \mathrm{C}$ for $30 \mathrm{sec}, 72^{\circ} \mathrm{C}$ for $30 \mathrm{sec}$ ("step-cycle" program). DQ $\alpha$ typing was performed on the amplified samples, as described in Materials and Methods.

\section{D1755 (YNZ22) Amplification}

Sample DNA (20 ng) was amplified in $50 \mu \mathrm{l}$ of PCR Mix containing $50 \mathrm{~mm}$ $\mathrm{KCl}, 10 \mathrm{mM}$ Tris- $\mathrm{HCl}$ ( $\mathrm{pH} \mathrm{8.3),} 0.85$ or $1.0 \mathrm{mM} \mathrm{MgCl} 2,140 \mu \mathrm{M}$ of each dATP, dCTP, dGTP, and dTTP, 25 pmoles of each primer SW26 (5' -GAGAGAAAGGTCGAAGAGTGAAGTGC-3' ) and SW37 (5' '-TCCCCCACATCCGCTCCCCAAGTTA-3'), and 2.5 units of Taq DNA polymerase (Perkin-Elmer Cetus, Norwalk, CT) unless otherwise indicated. The cycling reaction was done in a programmable heat block (DNA Thermal Cycler model TC480; Perkin-
Elmer Cetus) set to heat at $93^{\circ} \mathrm{C}$ (unless otherwise indicated) for $60 \mathrm{sec}$ (denature), and incubate at $68^{\circ} \mathrm{C}$ for 4 min (anneal/extend) by the "stepcycle" program. After 32 cycles (unless otherwise indicated), the samples were incubated an additional $10 \mathrm{~min}$ at $72^{\circ} \mathrm{C}$.

\section{Gel Electrophoresis of D1755 Amplification Products}

Seven microliters of amplified DNA was analyzed on $2 \%$ agarose gels. Running buffer and gel buffer were $1 \times$ TBE, both containing $0.5 \mu \mathrm{g} / \mathrm{ml}$ ethidium bromide. Electrophoresis was carried out for approximately $1 \mathrm{hr}$ at 100 volts; $250 \mathrm{ng}$ of the "100-bp ladder" (GIBCO BRL, Gaithersburg, MD) was run in one or more lanes of each gel to size the D17S5 alleles.

Acrylamide gel electrophoresis was performed on some samples using $5 \%$ precast acrylamide gels (Bio-Rad, Richmond, CA) and the MiniProtean II system (Bio-Rad, Richmond, CA). Five microliters of each amplified DNA sample was loaded per lane. Running buffer and gel buffer were $1 x$ TBE. Electrophoresis was carried out for approximately $1.5 \mathrm{hr}$ at 60 volts. DNA was detected on the gels by silver staining, using the Silver Stain Plus kit (Bio-Rad, Richmond, CA).

\section{RESULTS}

\section{Amplification of Native Genomic} DNA, Denatured Genomic DNA, and PCR Product at Low $\boldsymbol{T}_{\text {den }}$

Native genomic DNA, denatured genomic DNA, and dilute PCR product as described in Materials and Methods were each amplified using $T_{\text {den }}$ of $87-90^{\circ} \mathrm{C}$ and typed by using the reverse dot blot method. ${ }^{(6,7)}$ Amplification products from all three kinds of input DNA typed correctly as DQ $\alpha 1.1,4$ when the $T_{\text {den }}$ was set at $89^{\circ} \mathrm{C}$ or $90^{\circ} \mathrm{C}$, as shown in Figure 1 . However, when the $T_{\text {den }}$ was set at either $87^{\circ} \mathrm{C}$ or $88^{\circ} \mathrm{C}$, the DQ 1.1 allele was not detected for the denatured genomic DNA or the dilute PCR product samples, and so these samples had an apparent DQ $\alpha 4,4$ type. Amplification product yield from native genomic DNA was very low using $T_{\text {den }}$ of $87^{\circ} \mathrm{C}$ and $88^{\circ} \mathrm{C}$, as indicated by the weak typing signals. The typing system was designed such that a result is determined only if the control (C) dot is visible. ${ }^{(7)}$ Since neither of 


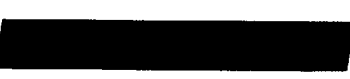

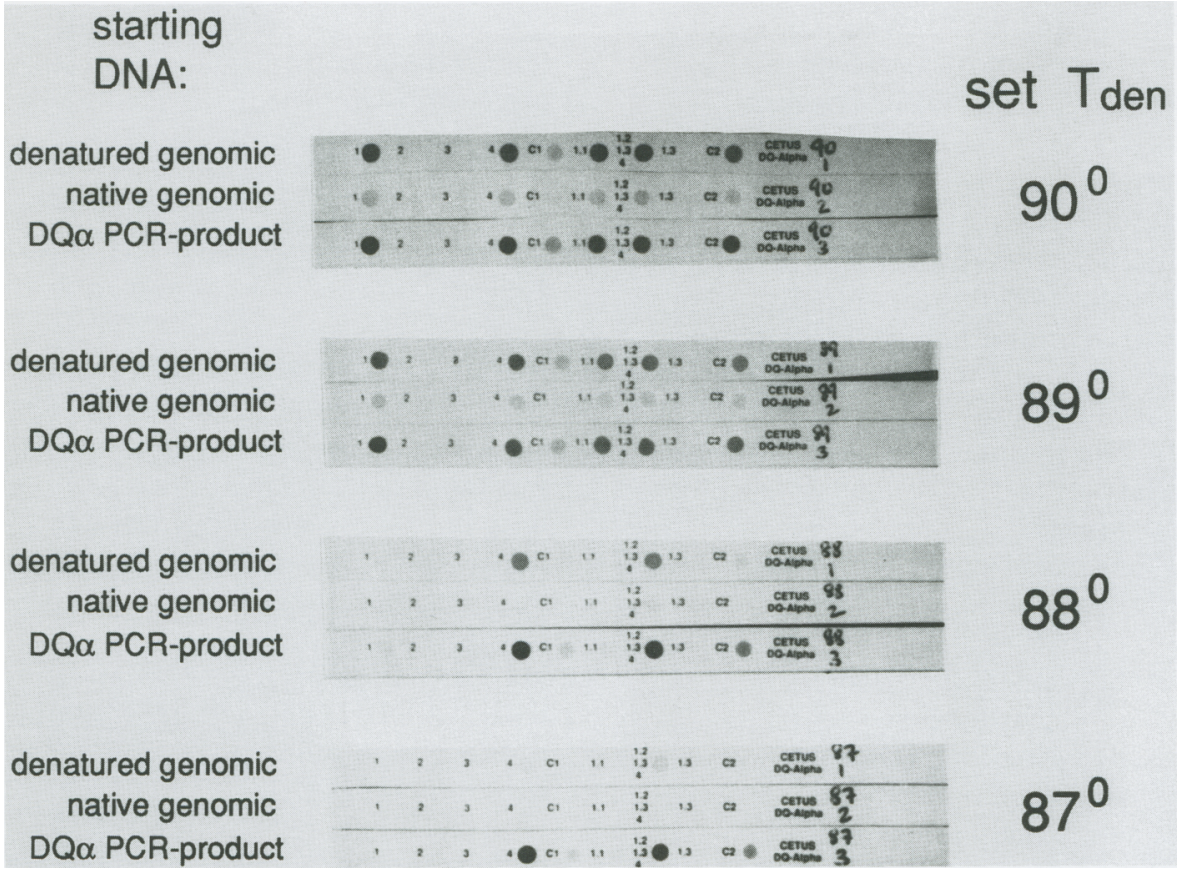

Figure 1 Preferential amplification of three different forms of input DNA as a furction of $T_{\text {den }}$. Denatured genomic DNA, native genomic DNA (non-denatured), or DQ $\alpha$ PCR product, all of $\mathrm{DQ} \alpha$ type $1.1,4$, were added to PCR mix and amplified using $87^{\circ} \mathrm{C}, 88^{\circ} \mathrm{C}, 89^{\circ} \mathrm{C}$, or $90^{\circ} \mathrm{C} T_{\text {den }}$. The DQ $\alpha$ typing results above indicate that preferential amplification (apparent DQ $\alpha 4,4$ type) is more readily detected using denatured genomic DNA or low-molecularweight templates (like PCR product) as input compared to high-molecular-weight, native genomic DNA. The probes (dots) labeled 1, 2, 3, and 4 distinguish the four major allelic types. The $\mathrm{C}$ probe dot is an intensity threshold control sequence that hybridizes to all alleles. The subsequent four probes are used in identifying the DQ $\alpha$ subtypes $1.1,1.2$, and 1.3.
DQ $\alpha 1$ alleles. This analysis predicts that the denaturation of the $\mathrm{DQ} \alpha 1$ alleles would require a $T_{\text {den }} 3-4$ degrees higher than for the other alleles.

\section{Test for Differences in Amplification Efficiency Between DQa Alleles at $94^{\circ} \mathrm{C} r_{\text {den }}$}

A variety of heterozygous DNA samples were used as input DNA to amplify the DQ $\alpha$ sequences an equivalent of 34 , 68 , and 102 cycles. This experiment was designed to test the hypothesis that there are no significant differences in amplification efficiency between the different $D Q \alpha$ alleles when the reaction is performed at $94^{\circ} \mathrm{C} T_{\text {den }}$. Any significant differences in amplification efficiency between $D Q \alpha$ alleles should result in greater and greater differences in the quantity of PCR product generated for the two alleles as the extent of amplification is increased. PCR product was diluted to about $10^{3}$ copies and reamplified after each 34 cycles to maintain the exponential phase of amplification.

The average efficiency of amplification per cycle for each pair of alleles was estimated to be approximately $90.7 \%$, which is equivalent to a total of these two samples had a visible " $C$ " dot, the typing was inconclusive and an incorrect typing would have been avoided. A model that accounts for these results is described in the Discussion section.

\section{Calculated Melting Profiles of the DQa Alleles}

A computer program (MELT) $^{(12)}$ was used to calculate $T_{\mathrm{m}}$ as a function of nucleotide position along the amplified portion of each of the DQ $\alpha$ allele sequences. This calculation predicts "domains" of the DNA fragment that melt at different temperatures. As shown in Figure 2, the DQ $\alpha 1.1,-1.2$, and -1.3 alleles contain such a domain in the middle of the second exon that has a significantly higher $T_{\mathrm{m}}$ than any region of the $D Q \alpha 2,-3$, and -4 alleles. This region of higher $T_{\mathrm{m}}$ corresponds to regions of higher GC content in the

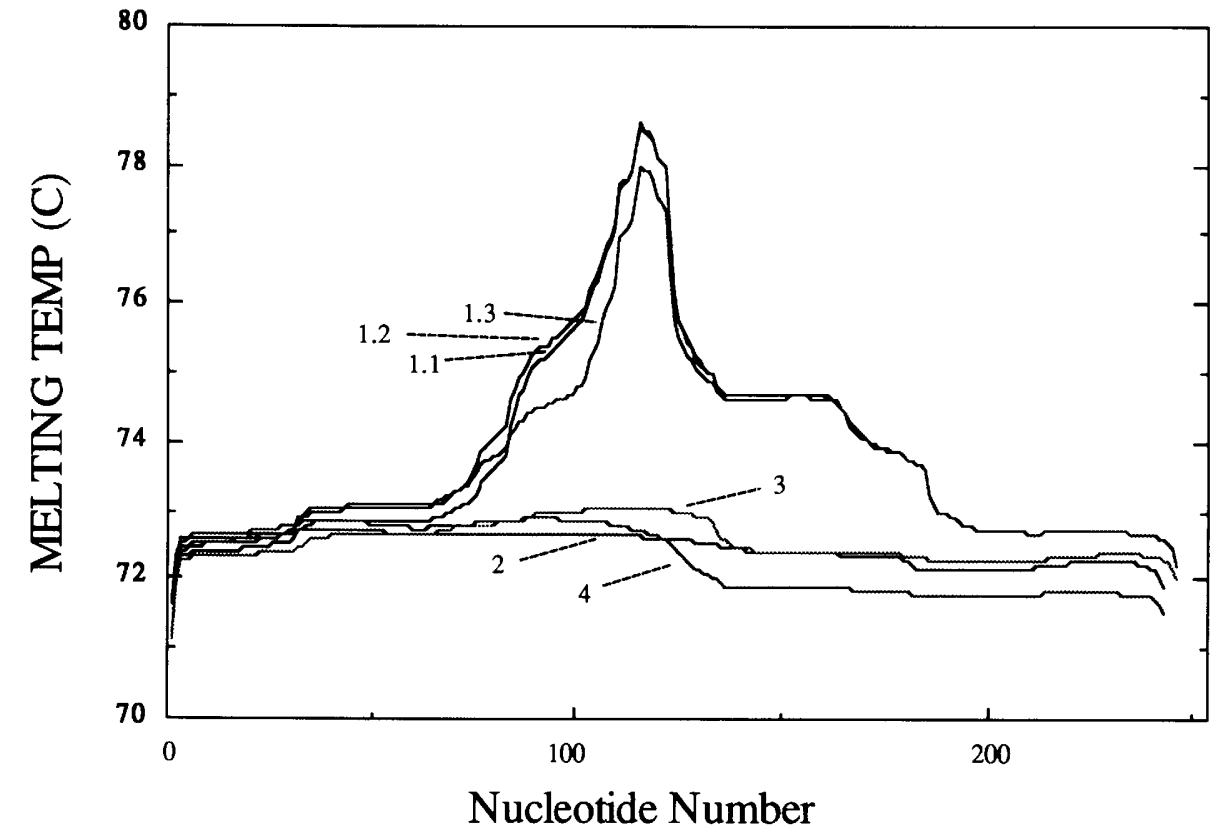

Figure 2 Comparison of the melting profiles for the DQ $\alpha$ alleles. The DQ $\alpha 1$ alleles contain a region of high $T_{\mathrm{m}}$ compared to the other DQ $\alpha$ alleles. 
95 doublings after 102 cycles. The relative dot intensities on the DNA probe strips for dots corresponding to the two different alleles remained unchanged from 34 to 68 to 102 cycles, as shown in Figure 3 . One can estimate that if one allele amplified at $100 \%$ efficiency ( $2^{95}$-fold increase) during the exponential phase and the other allele amplified at only 5\% less efficiency $\left(1.95^{95}\right.$-fold increase) there would have been an 11 -fold $\left(2^{95} / 1.95^{95}\right)$ relative increase in the amount of the more efficiently amplified alle1e. Thus, there is no evidence for differences in amplification efficiency between the DQ $\alpha$ alleles under standard reaction conditions.

\section{Amplification of DQa1.1,4 DNA in All 48 Wells of the Thermal Cycler Heat Block at $94^{\circ} \mathrm{C} T_{\text {den }}$}

One nanogram of native genomic DNA (DQ $\alpha$ type $1.1,4$ ) was amplified in all 48 wells of a thermal cycler model TC set at $94^{\circ} \mathrm{C} T_{\text {den. }}$ DQ $\alpha$ typing results indicated that all 48 samples typed correctly as $D Q \alpha 1.1,4$, as shown in Figure 4. Therefore, all 48 wells of the thermal cycler reached an adequate denaturation temperature under the standard conditions used to ensure amplification of both the DQ $\alpha 1.1$ and DQ $\alpha 4$ alleles.

\section{Effect of Various Treatments and Additions to Input DNA and PCR Mix on Preferential Ampllfication}

Various treatments were applied to either the input DNA or the PCR Mix before their use in amplifications done at $89^{\circ} \mathrm{C} T_{\text {den }}$. For each treatment or addition, five treated samples and two untreated controls were amplified together in a model TC thermal cycler. The DQ $\alpha$ type of the input DNA was 1.1,4 for all samples. The correct DQ $\alpha$ type 1.1,4 was obtained for all untreated control samples analyzed for each experiment. As indicated in Table 1, DQ $\alpha$ type 1.1,4 was also obtained for all five treated samples for each of treatments 1-4. However, preferential amplification (apparent DQ $\alpha 4,4$ type) was observed in all five treated samples for $100 \mathrm{mM} \mathrm{KCl}, 60 \mathrm{~mm} \mathrm{NaCl}$, and $120 \mathrm{~mm}$ ammonium acetate (treatments 5-7). Experiments for treatments 5-7 were repeated using $91^{\circ} \mathrm{C}$ or $92^{\circ} \mathrm{C} T_{\text {den. }}$. The results in Table 1 indicate, for example,

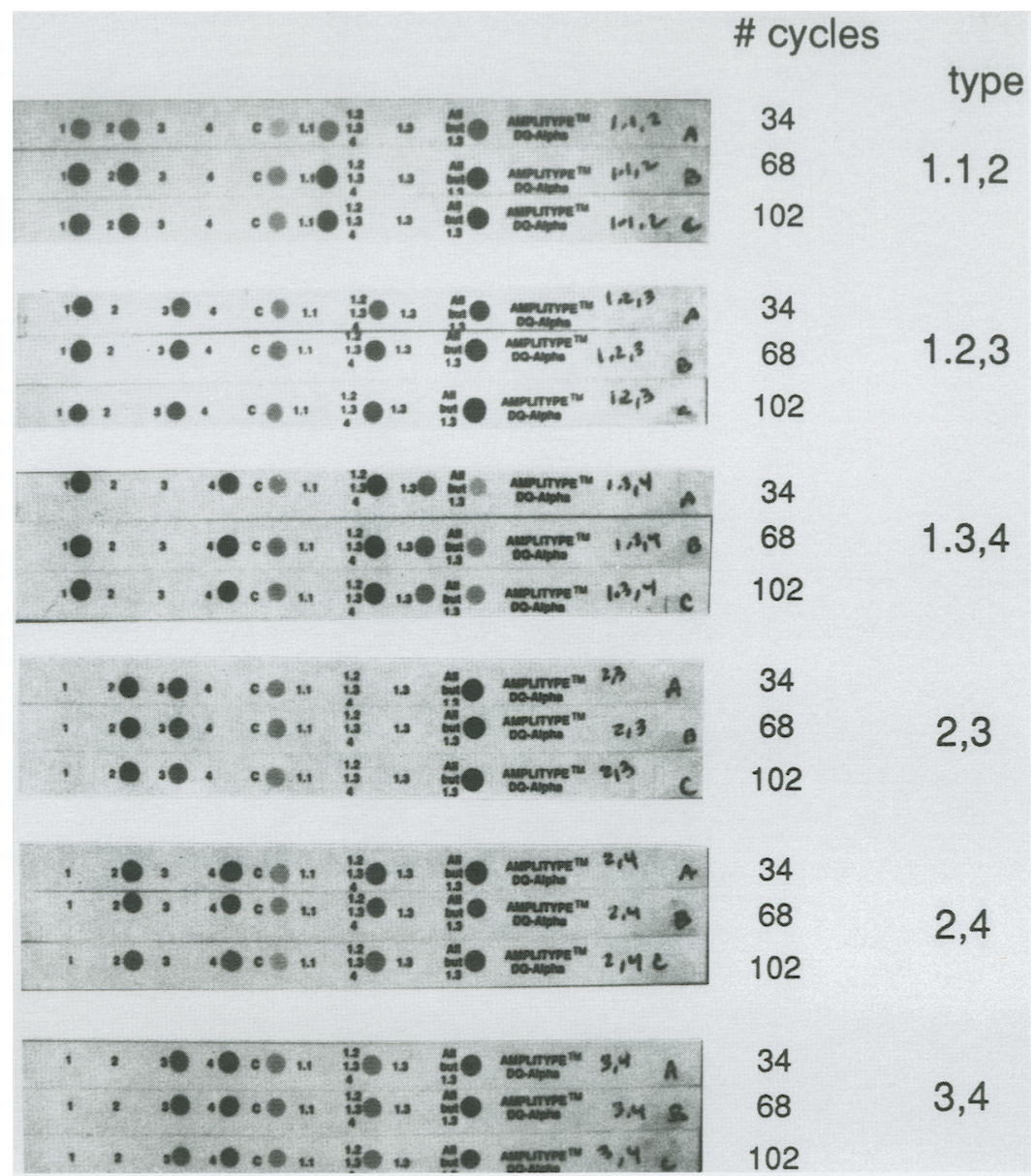

Figure 3 Extensive amplification of $\mathrm{DQ} \alpha$ heterozygote genotypes at $94^{\circ} \mathrm{C} T_{\text {den }}$ as a test for differences in amplification efficiency between alleles. Ten nanograms of each DNA was amplified for 34 cycles. An aliquot of the resulting PCR product was diluted and then amplified another 34 cycles, giving 68 cycles. This was repeated a third time, giving a total of 102 cycles of relatively exponential amplification. Any significant differences in amplification efficiency between the two alleles of a heterozygote would be expected to result in unequal dot intensities for the two alleles as the cycle number is increased.

that $92^{\circ} \mathrm{C} T_{\text {den }}$ was required to give the correct $\mathrm{DQ} \alpha$ type $1.1,4$ for all five samples containing $120 \mathrm{~mm}$ ammonium acetate. Higher concentrations of $\mathrm{KCl}, \mathrm{NaCl}$, or ammonium acetate than indicated in Table 1 resulted in no amplification product. Concentrations found to be inhibitory were as follows: $150 \mathrm{mM} \mathrm{KCl}, 120 \mathrm{~mm}$ $\mathrm{NaCl}$, and $200 \mathrm{~mm}$ ammonium acetate.

\section{Comparison of Preferential Amplification of Samples in the Model TC and TC480 Thermal Cyclers}

A model TC and two different model TC480 thermal cyclers were used to amplify denatured genomic DNA of type $D Q \alpha 1.1,4$ in all 48 wells of the heat block using $86-90^{\circ} \mathrm{C} T_{\text {den }}$. Temperature measurement of several wells of the heat blocks indicated that the average block temperatures were within $0.2^{\circ} \mathrm{C}$ for the three thermal cyclers tested. Table 2 indicates the percentage of samples showing preferential amplification at each $T_{\text {den }}$ for each of the thermal cyclers tested. A sample was defined as showing preferential amplification if the DQ $\alpha 1.1$ allele was not detected, or if the dots corresponding to the DQ $\alpha 1.1$ allele (" 1 " dot and "1.1" dot) were less intense than the "C," control dot. The results in Table 2 indicate the following: (1) preferential amplification of samples amplified in the model TC was associated with particular rows (see Table 2 ), whereas preferential amplification in the model TC480 thermal cycler was not associated with particular wells or rows. (2) Samples amplified in the 


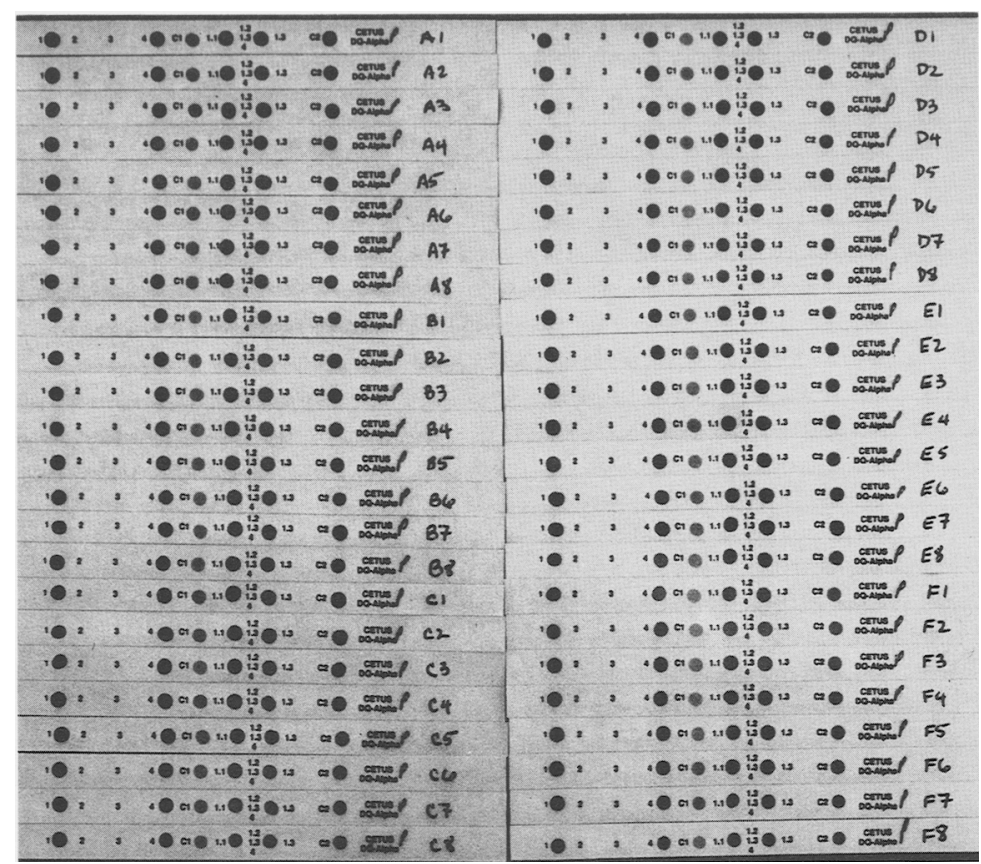

Figure $4 \mathrm{DQ} \alpha$ typing results from amplification of DQ $\alpha 1.1,4$ in all 48 wells of a model TC thermal cycler at $94^{\circ} \mathrm{C} T_{\text {den }}$. All 48 samples type correctly as $D Q \alpha 1.1,4$.

model TC480 thermal cyclers showed preferential amplification at a lower set $T_{\text {den }}$ than in the model TC. (3) Typing results for samples amplified in the TC480 were very consistent for a given $T_{\text {den }}$ across all wells of the heat block; 48/48 samples gave no amplification product at $86^{\circ} \mathrm{C} T_{\text {den }}, 47 / 47$ amplified samples typed as $D Q \alpha 4,4$ at $87^{\circ} \mathrm{C}$ (one sample did not amplify), and $48 / 48$ samples typed as $\mathrm{DQ} \alpha 1.1,4$ at $89^{\circ} \mathrm{C}$ $T_{\text {den }}$. This consistency of typing results reflects very even heating across all wells of the heat block for the model TC480.

\section{DQa Amplification of Low Number of Copies of Genomic DNA (Stochastic Fluctuation)}

Preferential amplification of alleles in a

TABLE 1 Effect of Various Treatments on the $T_{\text {den }}$ at Which Preferential Amplification is Detected

Number of treated samples showing preferential amplification (out of 5 total) $\left({ }^{\circ} \mathrm{C} T_{\text {den }}\right)$

Treatment

$89 \quad 91 \quad 92$

1. DNA boiled in Chelex

2. DNA from Chelex-extracted bloodstain

3. Increased DNA concentration (200 ng input)

4. $8 \mathrm{mM} \mathrm{MgCl}_{2}$

5. $100 \mathrm{mM} \mathrm{KCl}$

6. $60 \mathrm{mM} \mathrm{NaCl}$

7. $120 \mathrm{mM}$ ammonium acetate

0 \\ 0}

0

0

$1^{a}$

5

5

5
92

Input DNA and PCR Mix were treated as indicated in the first column. The DQ $\alpha$ type of the input DNA was $1.1,4$ for all samples. Five samples were amplified at $89^{\circ} \mathrm{C}$ for each of the treatments. Amplifications were repeated using $91^{\circ} \mathrm{C} T_{\text {den }}$ for treatments $5-7$, and using $92^{\circ} \mathrm{C} T_{\text {den }}$ for treatment 7 . The number of samples showing preferential amplification (apparent $\mathrm{DQ} \alpha 4,4$ type) is indicated for each treatment at each $T_{\text {den }}$ tested.

${ }^{a} D Q \alpha$ "1" and "1.1" dots for one sample $=$ "C" dot, indicating weak amplification of the DQ $\alpha 1.1$ allele. heterozygous sample could reflect the stochastic fluctuation associated with very small numbers of templates. To test this possibility, $25 \mathrm{pg}$ of $\mathrm{DQ} \alpha 1.3,2$ DNA (equivalent to approximately 7 copies of the DQ $\alpha$ gene) were amplified for 32 or 34 cycles. A control probe (the "C" dot) that hybridizes to all $\mathrm{DQ} \alpha$ alleles is immobilized at a lower concentration than the sequence-specific oligonucleotide probes to serve as a signal intensity threshold. ${ }^{(7)}$ The typing results shown in Figure 5 indicate that the " $\mathrm{C}$ " dot was not clearly visible for any of the samples amplified for 32 cycles, and the overall dot intensities of the remaining probes were too weak to read a type. However, the " $\mathrm{C}$ " dot was faintly visible for two of the four samples amplified for 34 cycles, and the "1" and "2" dots were not equivalent in intensity for three of these samples. The difference in intensity between the "1" and "2" dots is presumably due to adding an unequal number of $D Q \alpha 1.3$ and $D Q \alpha 2$ alleles to the PCR Mix. Limiting the number of cycles to 32 adjusts the sensitivity of the test so that detection of such low numbers of copies of starting DNA is not possitblle.

\section{Preferential Amplification of the D1755 VNTR}

The analysis of preferential amplification for a VNTR region was examined by varying the amount of Taq polymerase, the $T_{\mathrm{den}}$, and the number of cycles used in the amplification of D17S5. As shown in Figure 6, amplification of the longer allele of a heterozygote became less efficient as the number of units of Taq polymerase was reduced. The longer allele was not detected using 0.5 units of Taq polymerase. Even with the much more sensitive detection obtained by silver staining, the longer allele was not detected in one of the samples amplified using 0.5 units of Taq polymerase (Fig. 7).

Figures 8 and 9 show the results of D17S5 amplification of a heterozygous DNA sample at varying $T_{\text {den }}$ and varying numbers of cycles of amplification, respectively. These results indicate that preferential amplification of the shorter allele increased with the increasing $T_{\text {den }}$ and increasing cycle number. 
TABLE 2 Percentage of Samples Showing Preferential Amplification at Each $T_{\text {den }}$ Using all 48 Wells of the Model TC or Model TC480 Thermal Cyclers

\begin{tabular}{|c|c|c|c|}
\hline Set $T_{\operatorname{den}}\left({ }^{\circ} \mathrm{C}\right)$ & TC (\%) & TC480 (A) (\%) & TC480 (B) (\%) \\
\hline 90 & 0 & $\mathrm{NT}^{\mathrm{a}}$ & NT \\
\hline 89 & $\begin{array}{c}39 \\
\text { (wells A1-A8, B8, } \\
\text { E1, E2, F1-F8) }\end{array}$ & 0 & NT \\
\hline 88 & NT & $\begin{array}{c}10 \text { [Exp. 1] } \\
\text { (wells A8, B5, C6, } \\
\text { D6, F6) } \\
4[\text { Exp. 2] } \\
\text { (wells A1, B2) }\end{array}$ & 0 \\
\hline 87 & NT & $100^{b}$ & NT \\
\hline 86 & NT & $\begin{array}{l}\text { no amplification } \\
\text { for all } 48 \text { samples }\end{array}$ & NT \\
\hline
\end{tabular}

Input DNA was $20 \mathrm{ng}$ of denatured genomic DNA of DQ $\alpha$ type 1.1,4. Samples showing preferential amplification were those with an apparent DQ $\alpha 4,4$ type. The wells in which preferential amplification of samples was observed is also indicated.

${ }^{2} \mathrm{NT}$, Not tested.

b One sample out of 48 did not amplify; the others typed as DQ $\alpha 4,4$.

\section{DISCUSSION \\ Differential Amplification of DQa Alleles}

A model to explain the preferential amplification of DQ $\alpha$ alleles as a function of $T_{\text {den }}$ takes into account the strikingly different melting profiles predicted for $D Q \alpha 1$ alleles (Fig. 2). DQ $\alpha 1$ alleles contain a GC-rich domain that is expected to denature at a temperature several degrees higher than any other domain in the region of amplification. All other DQ $\alpha$ alleles lack this domain. Such a domain may fail to melt at a given $T_{\text {den }}$ even though the rest of the molecule is denatured. If so, the two DNA strands can never separate completely, and as the temperature drops during the annealing step of the PCR, the denatured portions of the fragment will reassociate instantaneously. This incomplete strand separation would effectively prevent primer annealing for these alleles, and thus prevent amplification. If, at this $T_{\text {den }}$, the other allele (a non$\mathrm{DQ} \alpha 1$ allele) is completely denatured, then it will be preferentially amplified, and an apparent homozygous DQ $\alpha$ type will be obtained.

The differences in GC content between the DQ $\alpha 1$ alleles and the other alleles is as follows: the $\mathrm{GC} \%$ is 51.2 (DQ $\alpha 1.1), 51.2(\mathrm{DQ} \alpha 1.2), 50.8$ (DQ $\alpha-$ 1.3) vs. 48.9 (DQ 22$), 48.8$ (DQ $\alpha 3$ ), and 48.5 (DQ $\alpha 4.1$ ). The DQ $\alpha 1.1$ allele has eight more GC pairs than the $\mathrm{DQ} \alpha 4.1$ allele. This difference may reflect the evolutionary observation, based on phylogenetic analysis, ${ }^{(14)}$ that the DQ $\alpha 1$ alleles diverged from the other $\mathrm{DQ} \alpha$ allelic lineages more than $25 \mathrm{mil}-$ lion years ago. Most polymorphic loci have alleles with much less sequence difference than the alleles at the DQ $\alpha$ locus, and thus would be expected to be less prone to differential denaturation.

Preferential amplification was found to be more readily detected using genomic DNA that was denatured prior to addition to the PCR Mix or low-molecular-weight templates (PCR product) rather than highmolecular-weight genomic DNA (Fig. 1). The relatively low denaturation temperatures at which preferential amplification occurs are apparently too low for the efficient initial denaturation of any DQ $\alpha$ allele of non-denatured high-molecular-weight genomic DNA. This lack of denaturation may be because of the proximity of the DQ $\alpha$ "amplicon" (region of DNA amplified) to another domain up- or downstream in the genomic DNA that fails to denature at the low $T_{\text {den }}$. If the strands of the molecule containing the amplicon then do not completely separate, efficient primer annealing, and thus amplification, cannot take place, as explained above. The fraction of moleunbroken DNA strand) to this higher $T_{\mathrm{m}}$ domain are probably responsible for the reduced yield of amplification product when amplification is performed at low $T_{\text {den }}$. Thus, degraded genomic DNA might be of sufficiently low molecular weight that this linkage is largely broken and preferential amplification is detectable at low $T_{\text {den }}$ even with non-denatured DNA.

No differences in amplification efficiency were found between any of the six DQ $\alpha$ alleles using a $T_{\text {den }}$ of $94^{\circ} \mathrm{C}$ (Fig. 3). Also, preferential amplification was not detected using $T_{\text {den }}$ cules that are physically connected (an

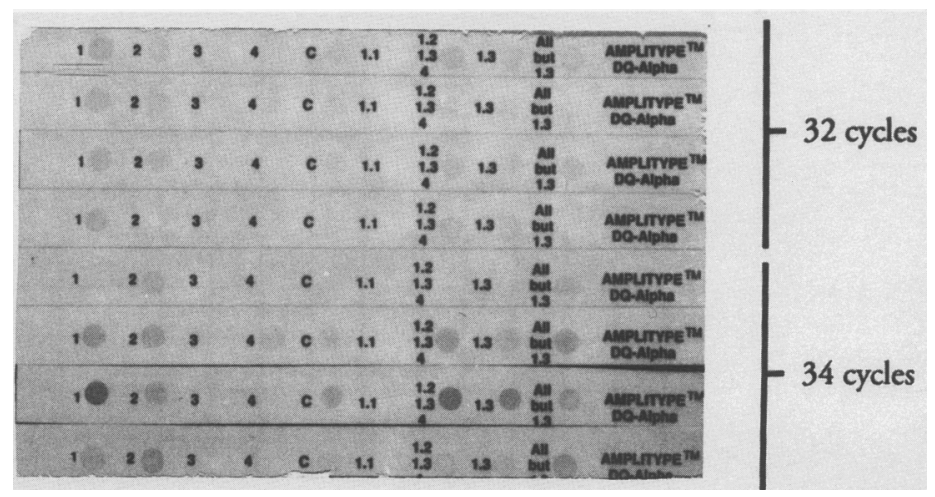

Figure 5. DQ $\alpha$ ampliflcation of low number of copies of genomic DNA. Apparent preferential amplification of alleles in a heterozygous sample can occur when amplifying from very low copy numbers of starting DNA. Twenty-five picograms of human genomic DNA of DQ $\alpha$ type $1.3,2$ was added to PCR mix and amplified for 32 or 34 cycles. The difference in intensity between the " 1 " and " 2 " dots at 34 cycles reflects an unequal number of DQ $\alpha 1.3$ and $\mathrm{DQ} \alpha 2$ starting template molecules. Amplification for only 32 cycles does not give sufficient sensitivity to detect such low numbers of copies of DNA. 


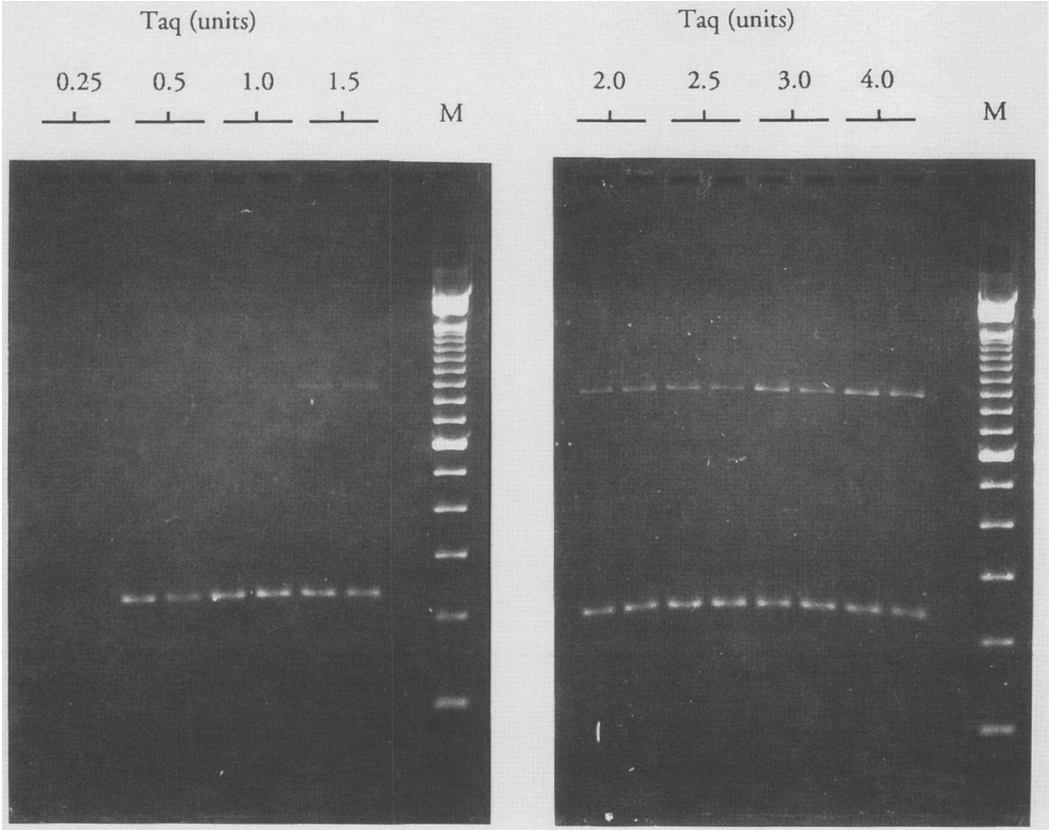

Figure 6 Effect of Taq polymerase on amplification of D17S5 alleles. Twenty nanograms of DNA was added to D17S5 PCR mix containing 0.25-4.0 units of Taq polymerase and amplified for 32 cycles. Seven microliters of amplified product was electrophoresed on $2 \%$ agarose gels and visualized with ethidium bromide. Yield of the longer allele decreases as the units of Taq polymerase is reduced. The longer allele is not detected using 0.5 units of Taq polymerase.

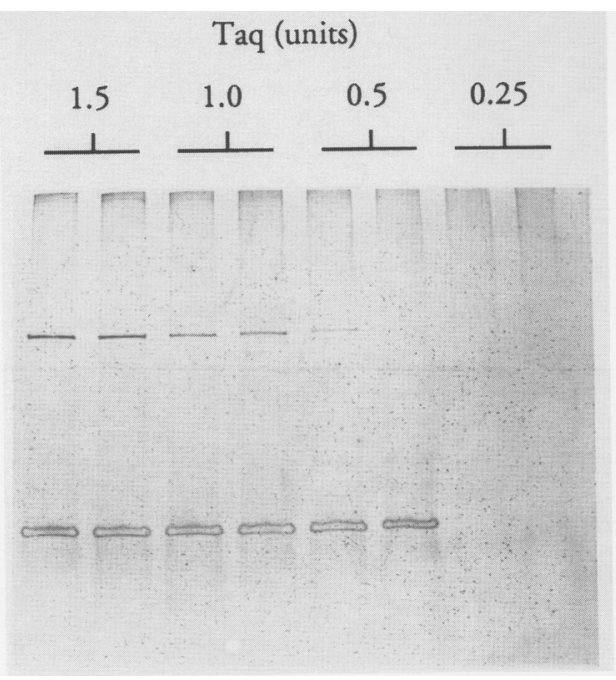

Figure 7 Effect of Taq polymerase on amplification of D17S5 alleles-acrylamide gel electrophoresis and silver stain detection. The samples above are the same samples as those shown on the gel appearing on the right side of Fig. 6 . Although silver stain detection is more sensitive than ethidium bromide detection, the longer allele is still not detected in one sample using 0.5 units of Taq polymerase. The diffuse staining of the shorter allele (bottom of gel) is due to overloading of the sample on the gel. greater than $89^{\circ} \mathrm{C}$, and otherwise standard conditions. However, preferential amplification was observed using $89^{\circ} \mathrm{C}$ to $91^{\circ} \mathrm{C} T_{\text {den }}$ when either $\mathrm{KCl}, \mathrm{NaCl}$, or ammonium acetate was added to the PCR Mix before amplification (Table 1). Apparently, the higher cation concentration contributed by these salts increases the duplex stability of both the DQ $\alpha 1$ and non-DQ $\alpha 1$ alleles, such that the $T_{\text {den }}$ required to completely denature the PCR product from both alleles is increased.

\section{The Effect of Thermal Cycler Well Temperature Variation}

The initial observation of $\mathrm{DQ} \alpha$ preferential amplification resulted from inadequate heating in one or two wells of a model TC thermal cycler. Typing results for samples amplified in the TC480 were very consistent across all wells of the heat block at all $T_{\text {den }}$ tested. Preferential amplification in the TC480 was not associated with particular wells or rows of the heat block. Because of the apparent absence of individual "cold wells" in the TC480 heat block, preferential amplification was detected at a lower set $T_{\text {den }}$ in the two TC480 models tested compared to the TC.

\section{Preventing $T_{\text {den }}$-dependent Preferential Amplification}

Using standard conditions, preferential amplification in the HLA-DQ $\alpha$ system does not occur if the $T_{\text {den }}$ is greater than $89^{\circ} \mathrm{C}$. The temperature of the thermal cycler heat block or the actual liquid temperature in a PCR tube can be measured using an electronic thermometer and thermocouple. ${ }^{(7)}$ Such measurement provides a check that the thermal cycler is reaching a temperature capable of denaturing all $D Q \alpha$ alleles. The DQ $\alpha 1.1,4$ control DNA provided in the AmpliType kit, thus, also serves as a control for preferential amplification. In general, periodically checking the calibration of the thermal cycler should eliminate the possibility of preferential amplification in the HLA-DQ $\alpha$ system.

\section{Differential Allelic Priming}

Allelic sequence differences giving rise to differential denaturation of alleles is not the only mechanism by which preferential amplification can occur in PCR-based typing systems. In principle, selective priming of alleles (due to sequence polymorphism under the pri-

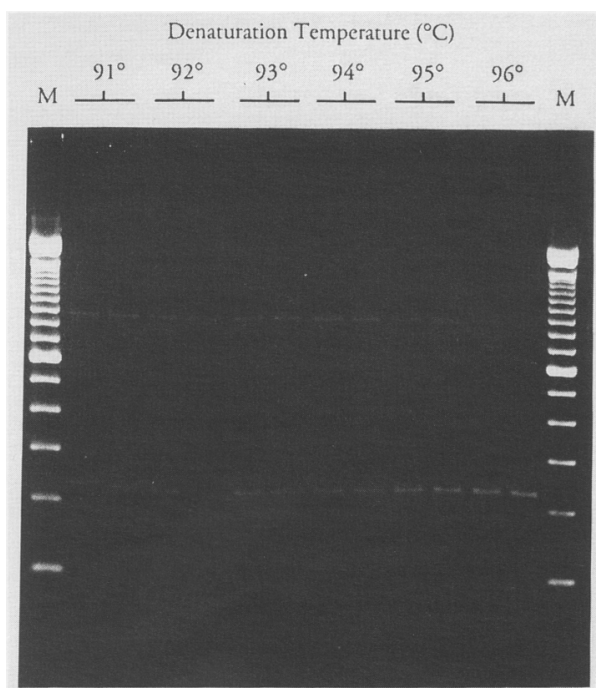

Figure 8 Effect of $T_{\text {den }}$ on amplification of D17S5 alleles. Preferential amplification of the shorter allele increases with increasing denaturation temperature $\left(T_{\text {den }}\right)$. 


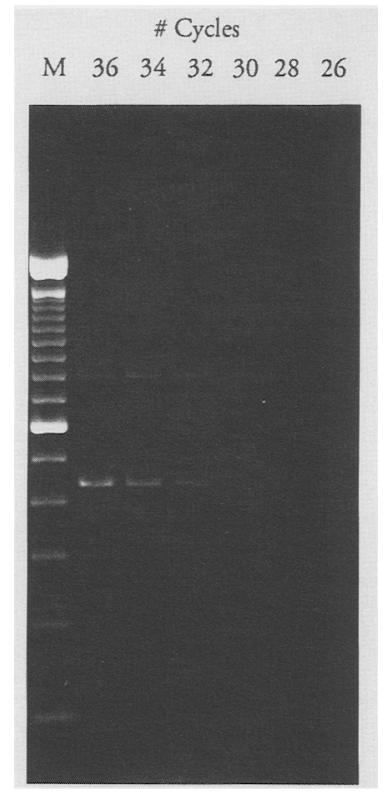

Figure 9 Effect of cycle number on amplification of D17S5 alleles. Preferential amplification of the shorter allele increases with increasing cycle number.

mers) could lead to differential amplification of two alleles. ${ }^{(15)}$ For example, some pairs of primers for the HLA-DQ $\beta$ (DQB1) locus amplify some but not all DQ $\beta$ alleles. ${ }^{(16)}$ For the $D Q \alpha$ primers GH26 and 27, however, there is no evidence for selective priming of alleles. The strategy of "allele-specific-amplification" or amplification refractory mutation system (ARMS) in which the primer is intentionally mismatched at the $3^{\prime}$ end with one of the alleles represents a general approach to genetic typing. ${ }^{(4)}$ The nature and position of the mismatched base pair between the primer and the target DNA sequence influence the efficiency of primer extension. ${ }^{(15)}$

\section{Preferential Amplification of Different-Length Alleles}

PCR typing systems that are based on the analysis of length polymorphisms (e.g., VNTR loci) can, under certain circumstances, reveal preferential amplification of the shorter allelic PCR product from a heterozygote ${ }^{(9,17)}$ (Figs. 6-9). It has been suggested that longer PCR products may be less efficiently denatured than shorter products. While this may, in fact, be the case for some VNTR regions of very high GC content, this hypothesis does not explain the preferential amplification ob- served at the D17S5 region (the 70-bp repeat unit for D17S5 is $64 \% \mathrm{GC}$ ). Increasing the $T_{\text {den }}$ does not increase the yield of the longer D17S5 PCR product in a heterozygote (Fig. 8). In fact, increasing the $T_{\text {den }}$ increases the amount of preferential amplification due, presumably, to the reduction in DNA polymerase activity resulting from thermal inactivation of the Taq enzyme (see below). The extent of preferential amplification is related to the size difference between the allelic PCR products. Preferential amplification also increases with the cycle number (Fig. 9) and the amount of starting DNA. Preferential amplification for VNTR regions is, therefore, related to the amount of PCR product. Under conditions of limiting enzyme, as is the case with high concentrations of PCR product, the probability of a complete primer extension may be greater for the shorter products. This explanation is consistent with the results of Taq polymerase titration which showed that decreasing the amount of enzyme increases the extent of preferential amplification (Figs. 6 and 7).

\section{Stochastic Fluctuation in Allelic Copy Number}

Preferential amplification due to stochastic fluctuation can occur when amplifying very low amounts of target DNA molecules; the possibility of an unequal sampling of the two alleles of a heterozygote (unless the DNA is amplified directly from unextracted diploid cells) is increased when only a few DNA molecules are used to initiate PCR (Fig. 5). This problem can be avoided by adjusting the cycle number such that approximately 20 or more copies of target DNA are required to give a typing result for that PCR system.

In general, understanding the different mechanisms-differential denaturation, preferential amplification of shorter allelic products in VNTRs under conditions of limiting enzyme or use of de-graded DNA templates, amplification of low numbers of copies of starting DNA, differential allelic priming-that can potentially give rise to preferential amplification allows the design of amplification protocols that can prevent the occurrence of this artifact.

\section{ACKNOWLEDGMENTS}

We would like to thank Nicola Fildes for contributing valuable data and Joel Bolonick for assistance with the computer program MELT. We are also grateful to Rebecca Reynolds and Sharon AItmeyer for review of the manuscript, and to Kathy Levenson for preparation of the manuscript.

\section{REFERENCES}

1. Saiki, R.K., D.H. Gelfand, S. Stoffel, S.J. Scharf, R. Higuchi, G.T. Horn, K.B. Mullis, and H.A. Erlich. 1988. Primer-directed enzymatic amplification of DNA with a thermostable DNA polymerase. Science 239: 487491.

2. Saiki, R.K., S. Scharf, F. Faloona, K.B. Mullis, G.T. Horn, H.A. Erlich, and N. Arnheim. 1985. Enzymatic amplification of $\beta$-globin sequences and restriction site analysis for diagnosis of sickle cell anemia. Science 230: 13501354.

3. Mullis, K.B. and F. Faloona. 1987. Specific synthesis of DNA in vitro via a polymerase-catalyzed chain reaction. Methods Enzymol. 155: 335-350.

4. Newton, C.R., A. Graham, L.E. Heptinstall, S.J. Powell, C. Summers, N. Kalsheker, J.C. Smith, and A.F. Markham. 1989. Analysis of any point mutation in DNA. The amplification refractory mutations system (ARMS). Nucleic Acids Res. 17: 2503-2516.

5. Wu, D.Y., L. Ugozzoli, B.K. Pal, and R.B. Wallace. 1989. Allele-specific enzymatic amplification of $\beta$-globin genomic DNA for diagnosis of sickle cell anemia. Proc. Natl. Acad. Sci. 86: 2757-2760.

6. Saiki, R.K., P.S. Walsh, C.H. Levenson, and H.A. Erlich. 1989. Genetic analysis of amplified DNA with immobilized sequence specific oligonucleotide probes. Proc. Natl. Acad. Sci. 86: 6230-6234.

7. AmpliType User Guide. 1990. Cetus Corporation, Emeryville, CA.

8. Comey, C.T., J.M. Jung, and B. Budowle. 1991. Use of formamide to improve the amplification of HLA $\mathrm{DQ} \alpha$ sequences. BioTechniques 10: 60-61.

9. Jeffreys, A.J., V. Wilson, R. Neumann, and J. Keyte. 1988. Amplification of human minisatellites by the polymerase chain reaction; towards DNA fingerprinting of single cells. Nucleic 
Acids Res. 16: 10953-10971.

10. Scharf, S.J., G.T. Horn, and H.A. Erlich. 1986. Direct cloning and sequence analysis of enzymatically amplified genomic sequences. Science 232: 1076-1078.

11. Bodmer, J., S.G.E. Marsh, and E. Albert. 1990. Nomenclature for factors of the HLA system, 1989. Immunol. Today 11: 3-10.

12. Lerman, L.S. and K. Silverstein. 1987. Computational simulation of DNA melting and its application to denaturing gradient gel electrophoresis. Methods Enzymol. 155: 482-501.

13. Walsh, P.S., D.A. Metzger, and R. Higuchi. 1991. Chelex 100 as a medium for simple extraction of DNA for PCR-based typing from forensic material. BioTechniques 10: 506-513.

14. Gyllensten, U. and H.A. Erlich. 1989. Ancient roots for polymorphism at the HLA-DQ $\alpha$ locus in primates. Proc. Natl. Acad. Sci. 86: 9986-9990.

15. Kwok, S., D.E. Kellog, N. McKinney, D. Spacic, L. Goda, C. Levenson, and J.J. Sninsky. 1990. Effects of primertemplate mismatches on the polymerase chain reaction: Human immunodeficiency virus type 1 model studies. Nucleic Acids Res. 18: 999-1005.

16. Bugawan, T.L. and H.A. Erlich. 1990. Rapid typing of HLA-DQB1 DNA polymorphism using nonradioactive oligonucleotide probes and amplified DNA. Immunogenetics 33: 163-170.

17. Horn, G.T., B. Richards, and K.W. Klinger. 1989. Nucleic Acids Res. 17: 2140.

Received December 5, 1991; accepted in revised form February 6, 1992. 


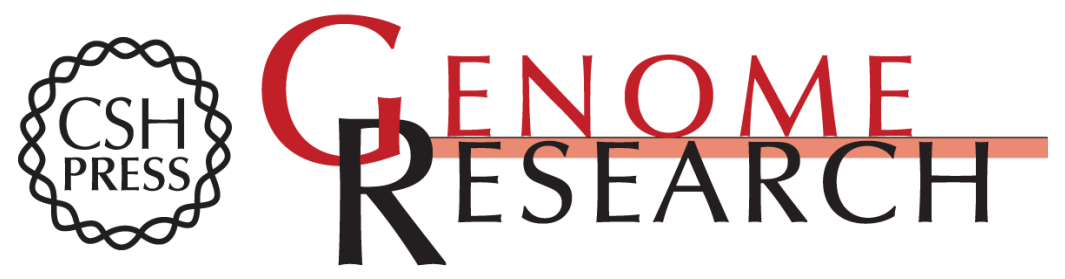

\section{Preferential PCR amplification of alleles: mechanisms and solutions.}

P S Walsh, H A Erlich and R Higuchi

Genome Res. 1992 1: 241-250

Access the most recent version at doi:10.1101/gr.1.4.241

References This article cites 16 articles, 5 of which can be accessed free at:

http://genome.cshlp.org/content/1/4/241.full.html\#ref-list-1

\section{License}

Email Alerting Receive free email alerts when new articles cite this article - sign up in the box at the Service top right corner of the article or click here.

\section{Affordable, Accurate Sequencing.}

To subscribe to Genome Research go to: https://genome.cshlp.org/subscriptions 